UDC 378:37.015.13:005.32

DOI: $10.52534 / \mathrm{msu}-$ pp.7(2).2021.109-117

\author{
Yue Zhang ${ }^{*}$, Shan Qing ${ }^{1}$, Iryna S. Kravets ${ }^{2}$ \\ ${ }^{1}$ Yangzhou University \\ 225009, 88 Daxue South Road, Yangzhou, People's Republic of China \\ ${ }^{2}$ Taras Shevchenko National University of Kyiv \\ 01033, 64 Volodymyrska Str., Kyiv, Ukraine
}

\title{
The Features of Modern Students' Internal Motivation for Physical Exercises
}

\author{
Article's History: \\ Received: 21.02.2021 \\ Revised: 18.04.2021 \\ Accepted: 12.06.2021
}

\section{Suggested Citation:}

Zhang, Y., Qing, S., \& Kravets, I.S. (2021). The features of modern students' internal motivation for physical exercises. Scientific Bulletin of Mukachevo State University. Series "Pedagogy and Psychology", 7(2), 109-117.

\begin{abstract}
The modern lifestyle contributes to the reduction of motor activity and muscle energy consumption in combination with neuropsychological overload. Based on this, the main purpose of the study was to identify the features of the modern students' internal motivation to engage in physical exercises. To achieve this purpose, the survey methods were used among 75 students of the Yancheng Institute of Technology, as well as the method of analysing the information received. The study identified the reasons for the lack of interest in sports on personal initiative, among which it is possible to highlight the lack of a clear example of parents, health problems, the programme of the training course, etc. It was determined that half of the surveyed students have a passive attitude to physical exercise and sports in general, since they attend physical education classes from time to time. Also, the work identified the indicators of motivation (depending on the year of studies). It was established that for the first-year students, the environment is of great importance (52\% of respondents), and for the thirdyear students - a healthy lifestyle ( $54 \%$ of respondents). Using the hierarchy analysis method, seven most significant motivational criteria were selected, which allowed determining that communication motives are the most important. This is due to the fact that adaptation in the team is of primary importance for junior students. The results of the experiment indicate that there is an indissoluble connection between internal and external factors of motivation in physical exercise. Only an integrated approach contributes to the inner interest of the younger generation. The results of the paper are of primary importance for university teachers during the preparation of curricula, which will contribute to the interest of students in the lesson
\end{abstract}

Keywords: physical activity, communication, hierarchy analysis method, questionnaire, sport, healthy lifestyle

\section{INTRODUCTION}

Internal motivation is an important component of human activity on their own initiative and based on their own choice [1]. Motivation presupposes energy, time, talent, will, and desire to get a successful job. Students require especially much effort to motivate them for a particular activity. Physical health problems are an important component of modern students since the exacerbation of chronic diseases of the cardiovascular system, back problems, joint pain, rapid fatigue is directly related to the lack of physical exercise. In addition, environmental and social problems affect health of the younger generation. The solution to this problem can be systematic physical education, which requires the psychological determination of students. Regular physical education classes do not solve this problem. Some students attend classes for their physical development, others - for the credit. Therefore, there is a need to motivate students to a healthy lifestyle.

As is known, students are the main labour category, so their motivation in physical exercise plays an important role. Showing interest in sports is a multi-stage process, from common knowledge and skills to serious knowledge of psychology, methods of physical education, and continuous engagement in sports. At the initial stage of training, students tend to face various problems in their studies, new loads and environments [2-4]. Physical activity decreases and, as a result, new health problems or old injuries arise. 
This problem can be solved by regular physical exercise. The main purpose is to motivate students to regularly attend physical education classes and to independently attend additional study circles. The successful result lies in the development of a number of motivations for the advantages of physical culture. Motivation implies an awakening to action, which is created on a psychological level. The studies have shown that among the internal motives for sports, it is possible to distinguish the following [5-7]:

- working capacity;

- stress resistance;

- having a leading position in the team;

- having a high level of physical fitness;

- healthy body.

The present education includes students' skills and practices. Universities of China, including the Yancheng Institute of Technology, pay great attention to the interests and motivation of students in the field of physical education, study methods to increase interest with the analysis of subjective factors influencing the values, priorities, and programmes of students' physical education in various fields [8]. Separately worth noting that the increase in the level of students' motivation for physical activity is based on the use of research in social, pedagogical, and natural sciences [9-13]. The motivation of students is heterogeneous, it depends on many factors: age, gender, as well as individual characteristics. V.M. De Oliveira [6], B.J. Almagro [14] and A. Granero-Gallegos [7] identified that undergraduate students perceive physical education as an academic discipline. Senior students characterise sports from the point of view of moral and emotional aspects. Therefore, the question of how to teach students to constantly take care of their health, to interest them in regularly applying forms and methods of physical education in everyday life, remains relevant. It was established that students do not have all the knowledge about the purposes of physical education and sports in general. I.R. Granizo [5] in his work indicates that successful learning depends on the development of habits and motivational climate at school age. Also, the interest in the subject depends on the psychological component, which allows developing an internal desire for learning.

It is worth noting that it is difficult to develop internal motivation for physical duties individually during learning, for this one needs a highly qualified teacher, a modernised system of higher education. The teacher must have a huge set of personal qualities and knowledge of the subject to develop the need for a healthy lifestyle. Therefore, the problem of physical education enters the scientific plane for determining the necessary skills, subtle features between the student and the teacher.

The paper is of practical relevance for university teachers since it analyses the main factors that affect the attendance of physical education classes and the implementation of the necessary standards. An important element in motivation is an understanding of the main priorities for students, thus, the paper conducted a questionnaire that will allow adjusting the lines in the educational process. Based on the above, the main purpose of the work was to study the issues of students' internal motivation to exercise, as well as to identify the most significant criteria using the method of hierarchy analysis.

\section{MATERIALS AND METHODS}

An empirical study was conducted to study students' internal motivation to exercise in 2019-2020 academic year. This study involved 75 students of the Yancheng Institute of Technology, who are studying in the first, second, and third years and have different levels of physical fitness. The age of the participants ranged from 17 to 20 years. To collect the data, classes were organised based on the curriculum schedule. The first class was attended by all students from the selected years (94 students), except for students who have restrictions and exemption from physical activity due to serious health problems. Data was collected from all participants in the experiment, but the results of 19 were rejected due to the lack of reliable information and the completeness of the data provided. Therefore, the remaining 75 students took part in the survey, taking into account the approval from the university management. All participants of the experiment were in the same conditions. Table 1 demonstrates respondents' characteristics. To collect the data (before the start of classes), the respondents were informed about the anonymity of the study and received instructions on how to fill out the questionnaires. All participants were divided into groups depending on the year of study.

Table 1. Distribution of respondents who took part in the survey

\begin{tabular}{|c|c|}
\hline \multicolumn{1}{|c|}{ Year of study } & Number of students \\
I & 16 \\
\hline II & 25 \\
\hline III & 75 \\
\hline Total amount & 75 \\
\hline
\end{tabular}

In the course of an empirical study, students were offered a written survey aimed at studying the most significant motives for physical education and sports. The authors focus on the questionnaire method, since it is more productive and flexible for obtaining and processing information [15]. In the process of analysing scientific literature, survey, and questionnaire, the authors identified seven main motives for physical education in higher educational institutions: communicative, health-improving, psychologically significant, motor-activity, competitive, cognitivedeveloping, creative. Later, using the method of hierarchy analysis, the most predominant personal motivations were determined. It is worth noting that the method of hierarchy analysis is a mathematical tool for system analysis and helps to identify the most significant criteria, allows rationally structuring a complex problem and conduct a comparative 
assessment of alternative solutions [16]. To determine the correctness of the matrix, the consistency index was calculated (1):

$$
I_{y}=\frac{\lambda_{\max }{ }^{*}-n}{n-1}
$$

where $\lambda_{\max }$ is the geometric total value of the matrix; $n$ is the number of criteria.

In addition, the study used the survey method to determine the attendance of physical education classes, as a result of which different data were obtained, and it was also identified that not all students are interested in physical education classes since they are undifferentiated and contain monotonous technique in repeating exercises. Thus, the answers to the question from the questionnaire "Why do students not play sports on their own initiative?" made it possible to establish the gradation of results depending on the year of studies. Among the answers were the following options:

- lack of a clear example of parents;

- health problems;

- training course programme;

- other.

At the same time, the answers to the question "What motivates you to exercise?" helped to identify interesting patterns distributed across the years of studies. The older the students, the more important a healthy lifestyle is for them. Using the analysis method, it was found that the use of an individual approach to physical education lessons will speed up the process of adaptation, and in the future, the motivation of students. Statistical data processing was carried out based on the information received during the questionnaire. To achieve a more complete analysis, it is necessary to investigate all processes from the level of the scientific organisation to the analysis of materials. Therefore, to get the results, the data was processed using Microsoft Excel.

\section{RESULTS AND DISCUSSION}

To study the motivation of students regarding physical exercises, a questionnaire was conducted, which took place in the course of classroom work. Based on the results of a survey in 2019-2020 among students of the Yancheng Institute of Technology, it was identified that the majority are not motivated to engage in physical activity on their own initiative. Figure 1 demonstrates information about students' attendance at different years of physical education lessons.

Based on the diagram, it is evident that students attend physical education classes from time to time, they find another activity if there is an opportunity. This diagram once again confirms the lack of motivation in physical education lessons. The reason why students do not play sports is indicated in Table 2 based on the results of the questionnaire.

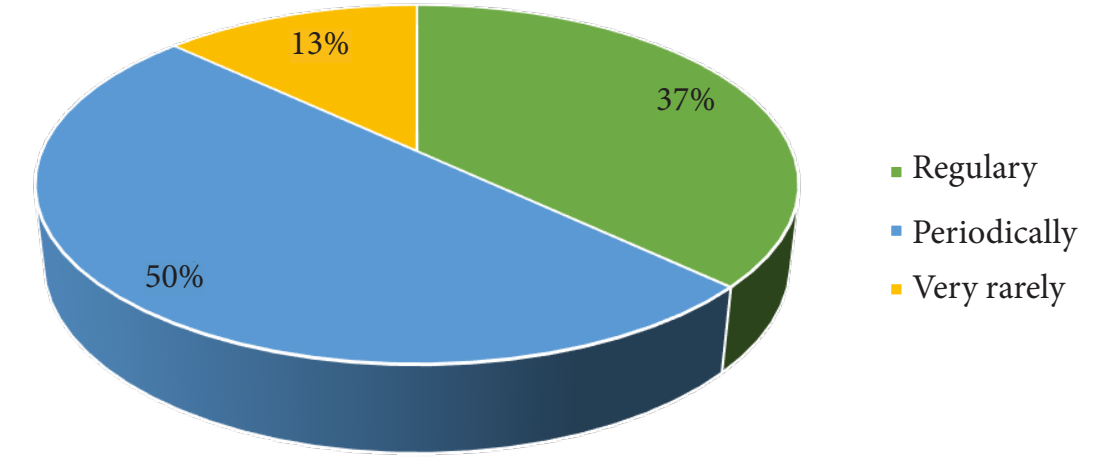

Figure 1. The results of the survey among students of the I, II, III year of studies on attendance of physical education lessons

Table 2. The statistics of answers to the question of the questionnaire "Why do students not play sports on their own initiative?"

\begin{tabular}{c|c|c|c}
\multicolumn{2}{c}{ Reason } & \multicolumn{2}{c}{ Survey results depending on the year of studies, \% } \\
& I year & II year & III year \\
\hline Lack of a clear example of parents & 53 & 29 & 37 \\
\hline Health problems & 18 & 14 & 13 \\
\hline Training course programme & 12 & 27 & 21 \\
\hline Other & 27 & 51 & 31 \\
\hline
\end{tabular}

Notes: respondents had an opportunity to choose more than one answer option

In the main category of students, the attitude to physical exercises becomes more passive. Clearly, this is due to the lack of a clear example of relatives, parents, or personal beliefs. There are also students who do not like the programme of the training course, which does not contribute to the motivation to play sports in the physical education class or in the future in optional classes, in gyms. In Table 2, the "other" box refers to lack of desire, laziness, or other hobbies or activities. It is worth noting that third-year students are more focused on a healthy lifestyle, despite the fact that there are a number of other classes. Objective factors that affect the lack of motivation for physical exercise include health problems, as well as a significant load according to the curriculum. In this regard, it can be concluded that 
there is no physical culture among students' cultural values since it does not meet the quality requirements.

At the same time, the survey provided an answer to the question "What motivates you to exercise?". An important indicator of motivation in this case is the teacher and the closest circle of communication. Table 3 demonstrates the results of the questionnaire.

Table 3. The statistics of answers to the question "What motivates you to exercise?"

\begin{tabular}{|c|c|c|c|}
\hline \multirow{2}{*}{ Motivation indicator } & \multicolumn{3}{|c|}{ Survey results depending on the year of studies, \% } \\
\hline & $1^{\text {st }}$ year & $2^{\text {nd }}$ year & $3^{\text {rd }}$ year \\
\hline Teachers & 23 & 20 & 17 \\
\hline Immediate environment (friends, parents) & 52 & 47 & 28 \\
\hline Healthy lifestyle & 18 & 19 & 54 \\
\hline Other & 14 & 19 & 22 \\
\hline
\end{tabular}

Notes: respondents had an opportunity to choose more than one answer option

Table 3 shows that the greatest motivation is the immediate environment and a healthy lifestyle, which occupies a significant part of the students of the $3^{\text {rd }}$ year. Other indicators include appearance, the ability to lose weight, have a healthy psychological condition, a high grade, etc. But for first-year students, these indicators remain in last place (14\%), because, first of all, it is important for them to adapt to the educational process, which is significantly different from the school curriculum. Physical education classes promote distraction from mental work and negative emotions. Also, physical culture contributes to the development of self-control skills and the improvement of skills, their development. Thorough preparation of the theoretical and practical part, the absence of monotony, the emphasis on the creative component contributes to an increase in attendance at physical education lessons, and also allows improving the physical training of students and, above all, strengthening health. In addition, as one of the methods of increasing motivation, the possibility of choosing the sport that students like the most was considered, as a result of which the questionnaire provided the question "What kind of sport would you like to do?" (Fig. 2).

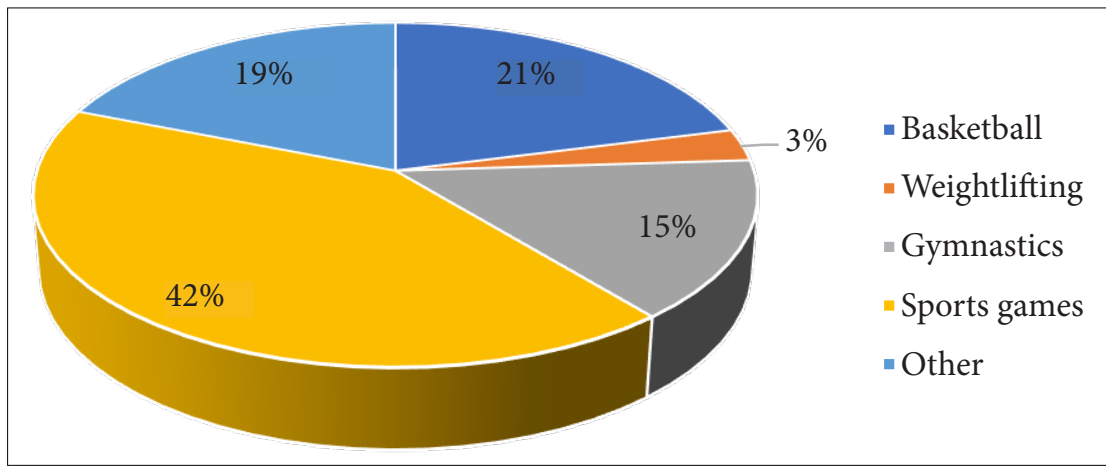

Figure 2. The statistics of answers to the question "What kind of sport would you like to do?"

Figure 2 shows that students of all years of studies prefer sports games (42\%) and basketball (21\%), and are least interested in weightlifting (3\%).

Thus, based on the received answers of students in the course of research, 7 important motivational elements were selected, and the most significant ones were identified using the method of hierarchy analysis, which is subjective, including communicative, health-improving, motor-activity, competitive, cognitive-developing, creative, psychologically significant motives. These criteria were chosen because these elements affect the attendance of physical education classes. Health-improving motives were selected because sports are one of the main ways to promote health. Regular exercise has a positive effect on the body and helps to strengthen the immune system. Communication in the classroom promotes new acquaintances, joint activities, and group unity. Motor-activity motives are based on the performance of special physical exercises that promote the switching from mental to physical work. Competitive motives are based on the student's desire to improve their standards.
Cognitive-developmental motives are closely related to competitive ones, since they are based on the desire to achieve the best results, to learn the physical abilities of the body, to increase physical fitness. Regular sports activities provide opportunities for the development of a creative personality. Psychologically significant motives contribute to a positive impact on the mental state of students, self-confidence, the removal of emotional stress, the restoration of mental performance. Each of the seven categories is indispensable in shaping students' interest in sports. In this regard, the criteria for comparison were:

1. Communicative motives.

2. Health-improving motives.

3. Psychologically significant motives.

4. Motor-activity motives.

5. Competitive motives.

6. Cognitive-developmental motives.

7. Creative motives.

The methods for comparing paired criteria with each other are given in Table 4 . 
Table 4. The matrix of paired comparisons of the criteria level

\begin{tabular}{c|c|c|c|c|c|c|c|c|c|c} 
Criteria & $\mathbf{1}$ & $\mathbf{2}$ & $\mathbf{3}$ & $\mathbf{4}$ & $\mathbf{5}$ & $\mathbf{6}$ & $\mathbf{7}$ & $\mathbf{W}^{*}$ & $\mathbf{W}^{*}$ of norms \\
\hline 1 & 1 & 4 & 3 & 2 & 3 & $1 / 4$ & 5 & 1.90 & 0.21 \\
\hline 2 & $1 / 4$ & 1 & $3 / 4$ & $2 / 4$ & $3 / 4$ & $1 / 7$ & $5 / 4$ & 0.54 & 0.06 \\
\hline 3 & $1 / 3$ & $4 / 3$ & 1 & $2 / 3$ & 1 & $1 / 5$ & $5 / 3$ & 0.72 & 0.08 \\
\hline 4 & $1 / 2$ & $4 / 2$ & $3 / 2$ & 1 & $3 / 2$ & $1 / 3$ & $5 / 2$ & 1.09 & 0.12 \\
\hline 5 & $1 / 3$ & $4 / 3$ & 1 & $2 / 3$ & 1 & $1 / 5$ & $5 / 3$ & 0.72 & 0.08 \\
\hline 6 & 4 & 7 & 5 & 3 & 5 & 1 & 6 & 3.85 & 0.42 \\
\hline 7 & $1 / 5$ & $4 / 5$ & $3 / 5$ & $2 / 5$ & $3 / 5$ & $1 / 6$ & 1 & 0.45 & 0.05 \\
\hline$\Sigma$ & 6.62 & 17.47 & 12.85 & 8.23 & 12.85 & 2.29 & 19.08 & 9.27 & 1.00 \\
\hline
\end{tabular}

The consistency index of the matrix according to equcation 1 is:

$\lambda_{\max }=6.62 * 0.21+17.47 * 0.06+12.85 * 0.08+8.23 * 0.12+$

$+12.85 * 0.08+2.29 * 0.42+19.08 * 0.05=7.21$.

$$
I_{y}=\frac{7.21-7}{6}=0.035<0.2
$$

When comparing the communicative and healthimproving motives, it can be seen from Table 4 that the communicative ones have a considerable advantage. This is because, during the first years of study, adaptation in the group and effective socialisation play an important role.
Health-improving motives are of secondary importance since not all students highlight the greatest importance of this criterion. Based on the questionnaire, the preference for a healthy lifestyle is given by third-year students. Therefore, this criterion is not relevant for all groups of students. The consistency index of the matrix is 0.035 , which indicates that the matrix is correct, since the index is less than 0.2.

Based on the conducted research, to increase motivation for sports, mechanisms for upgrading the curriculum were proposed among students (Fig. 3.)

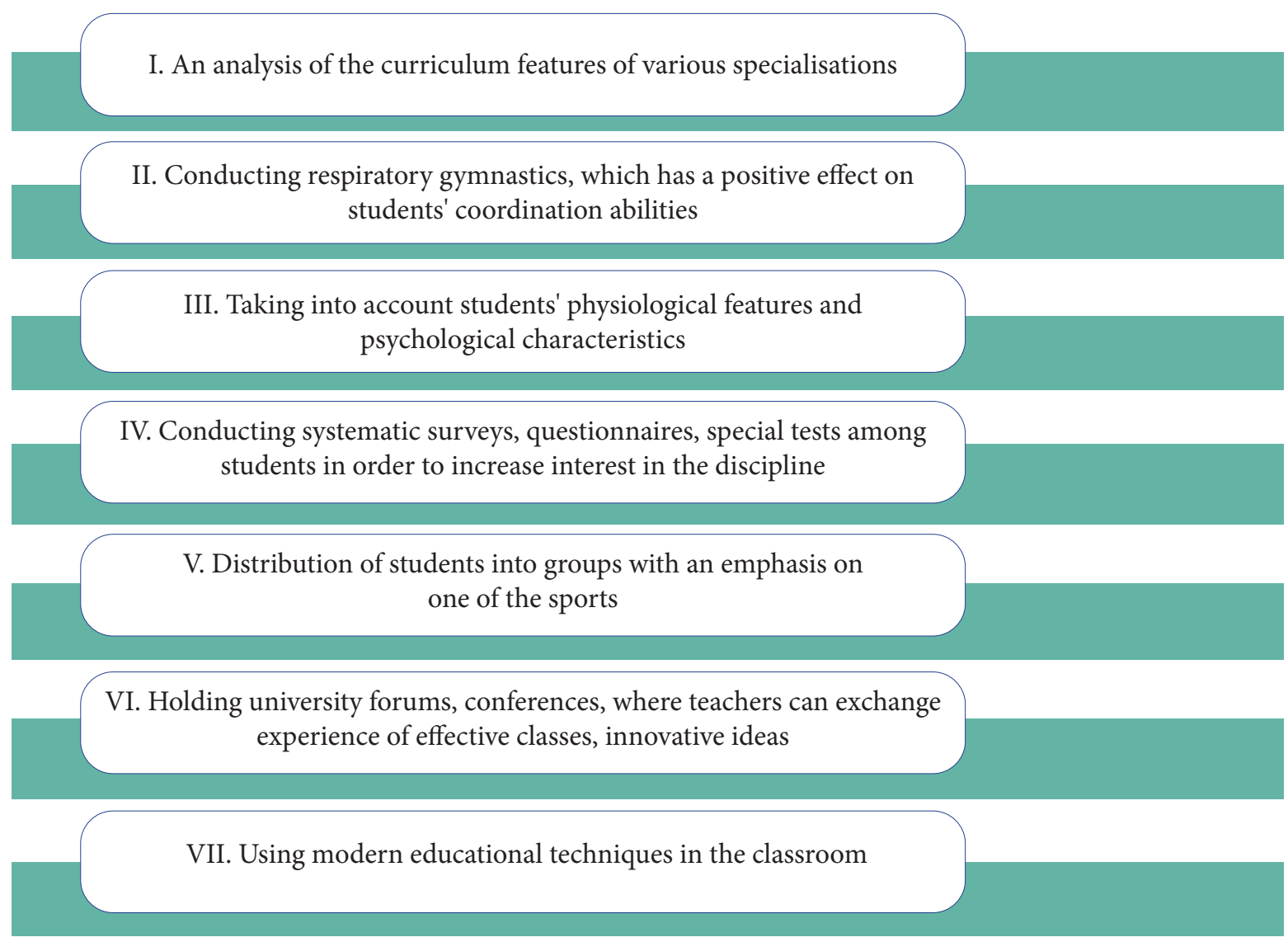

Figure 3. The mechanisms for modernising the curriculum to increase motivation for sports

First of all, the analysis of the curriculum features of each specialisation is important, since it will allow determining the workload of students. For example, for students of technical specialisations, it is necessary to put physical education lessons between other subjects. This will allow distributing the mental workload. The programme should include more exercises to strengthen back and neck because due to an inactive lifestyle, problems with the musculoskeletal system occur. At the same time, proper breathing management helps to get rid of stress and mental workload. Respiratory gymnastics plays a special role in improving the functional capabilities of the respiratory system in order 
to restore free breathing. Breathing movements help to increase activity and concentration, which is one of the key elements for training; it helps to improve physical fitness. The more motor skills a student has, the easier it is to adapt to physical exertion and achieve better results when passing the standards.

It is also worth noting that taking into account the physiological features and psychological characteristics of students plays an important role in the interest in physical exercise. It is necessary to take into account the fact that there are students who have health problems (for example, seasonal allergies); or have psychological trauma associated with excess weight. These points should be clarified by a teacher or a school psychologist before forming the curriculum. Based on the information received, the curriculum for these students should be adjusted taking into account the physiological and psychological characteristics. For example, $18 \%$ of first-year students, $14 \%$ of second-year students, and $13 \%$ of third-year students have health problems. In general, the importance of conducting systematic surveys and questionnaires among students in this aspect is justified. This will allow identifying all the problems at the initial stage, as well as those that appeared during the training process. Constant monitoring of the situation will promote interest in the educational process.

In addition, the distribution of students into groups with an emphasis on one of the sports will help to maintain a competitive spirit and increase motivation. The type of sport that students prefer can be determined using a sociological survey. At the same time, holding university forums and conferences will make it possible for teachers to exchange experience of effective classes and innovative ideas. Due to quarantine restrictions, online conferences have become more popular. The most common are ClickMeeting, RingCentral, Microsoft Teams, Proficonf. It is also worth noting the use of online space, as well as the use of visual electronic and methodological manuals as modern information technologies; videos, presentations; exchange of teachers' experience through the network space, which will allow introducing new teaching methods and improving the effectiveness of classes among students.

One way or another, the problem of students' motivation to physical culture remains relevant, and therefore it would be appropriate to consider other studies of this issue to compare the data obtained. For example, the work of M. Shin and S. Bolkan [17] demonstrates that teachers' intellectual behaviour is of direct importance for the internal motivation of students. In this study, students' main needs were realised in the form of students' engagement, independence, and academic support between them. For his part, A. Gil-Arias, based on an experimental volleyball group, analysed the influence of mixed learning games on students' motivation [18]. The authors have developed a special programme since the existing one faces additional time constraints in the educational process of Spain. In addition, the study identified that the development of an innovative programme can improve students' motivational responses in physical education, and for a certain group of people, a healthy lifestyle plays an important role in motivating them to exercise. The work of N. Román et al. determines that the motivation for a healthy lifestyle, especially a healthy diet, depends on the interethnic similarity, the culture of a particular people [19]. At the same time, the work of S. Janke [20] analysed students' motivation to study in the first years in the beginning and at the end of the year based on a questionnaire. It was established that internal motivation contributes to the orientation towards learning goals and satisfaction from the chosen specialisation, and the orientation towards material incentives negatively affects learning. The paper demonstrates the relationship between students' achievements in educational programmes over time and adaptation to the educational process. The main conclusion is that the well-being, motivation for achievements in the educational process depends on how responsibly students approach the choice of profession and curriculum. This applies not only to physical education, but also to all educational programmes. In the same study, the main focus is on the internal motivation for exercise.

In the context of research on motivation to exercise, it is worth saying that an important element that affects the preservation of health is sports. The value orientations of behaviour, the physical, psychological, and social state of society depend on it. The insignificant level of motivation to a healthy lifestyle in the younger generation is caused by the lack of a formed organisation of physical culture and health promotion. Therefore, the introduction of new organisational tools and methods contributes to purposeful and effective work to preserve and increase the love for sports. For example, the study of K. Aoyagi et al. [21] indicates that the lack of physical activity in the younger generation causes concern in the world. The paper demonstrates the factors that influence the motivation of Japanese customers. The study was divided into internal (interest in sports, responsibility) and external factors (team atmosphere, support, personal growth, national culture, etc.). These factors were established using a social survey among primary and high school students.

The paper by O. Kiremitci et al. [22] investigated the relationship between academic motivation and students of different faculties. It is identified that internal dynamics caused by differences between faculties based on their curricula, may be the cause of differentiation within the spiral of relationships. In addition, the employment conditions of graduates and the achievements of students based on sports experience affect motivation. The authors claim that external motivation is directly related to self-control, selfesteem, perception of personality, and personal significance. At the same time, in the paper "The use of information and communication technologies in the organisation of additional recreational activities of students, taking into account the type of motivation", the authors approached the study differently [23]. E.V. Gavrishova and A.S. Grachev believe that students who are focused on achieving high results show more initiative in independent physical education than the younger generation, which is focused on avoiding failures.

An important work for comparison is the work of R. Kerstajn et al. [24], in which differences in motivation 
between countries were established using an analysis of variance and a correlation matrix. The results showed that motivation is influenced by the national culture, where parents play an important role. The study of the relationship between mixed synchronous learning environments, student motivation, and cognitive engagement was presented in the work of Y. Shi et al. [25]. The main purpose of this study was that teachers and practitioners should consider pedagogical, social, and technical opportunities to change the motivating and engaging learning environment. For a detailed study of complex psychological processes that are directly related to the motivation of behaviour, S. Samendinger and C.R. Hill [26] considered the relationship between the exercise pattern and self-determined exercise motivation rules. The constructed model confirmed the division of people into three different types, which have unique features, and equally affect motivation. In addition, in the paper by S. Khalilzadeh and A. Khodi [27], a study was conducted among teachers and students, where the relationship between the personal traits of teachers and the motivation of students was shown. In this work, the feedback is shown on how the motivation of students directly depends on the prepared programme, the level of teacher's knowledge and personal qualities.

As is evident, the problem of internal motivation has repeatedly become the subject of research, which indicates its relevance. On the example of the conducted empirical research and the analysed scientific works, the ways of motivating students to physical culture are considered, the use of which can increase both the interest in sports and improve the lifestyle in general.

\section{CONCLUSIONS}

Motivation for physical education is a special state of the individual, aimed at achieving fitness and efficiency. Physical education is not only the implementation of the standards established by the university, but also health care, support for psychological and emotional state, support for working capacity and stress resistance. The system of physical development should contribute to the development of personal motivation, effective educational and professional activities, self-improvement, and self-development.

This work established how often students attend physical education classes using a questionnaire among students of the I, II, and III years of studies of the Yancheng Institute of Technology. It was determined that $50 \%$ of the students (out of 75 people) are periodically attending classes. The main reason for the lack of motivation in sports on personal initiative among first-year students is the lack of a clear example (53\%); II year - other reasons: hobbies, lack of desire (51\%); III year - the lack of an example of parents and other interests occupy practically the same percentages (37\% and $31 \%$, respectively). In addition, the work identified the sport that is most popular among students. $42 \%$ prefer sports games, and only $3 \%$ are interested in weightlifting.

The method of hierarchy analysis allowed the authors to determine seven most significant criteria that affect the motivation of students. This method is subjective, but at the same time a serious tool that contributes to the structuring of the problem and the comparative evaluation of various solutions. It was established that the most significant motivational criteria are communicative since communication plays an essential role in the development of a healthy atmosphere in the group, its unity. In addition, the paper presents the mechanisms that need to be taken into account by both teachers and students to increase motivation for physical exercise. The development and implementation of an innovative curriculum, taking into account the physiological and psychological characteristics of students, holding forums, conferences, and receiving feedback contributes to the motivation to engage in physical exercises.

This study describes the important components that affect the motivation of students to engage in physical education. When drawing up training programmes, teachers should pay attention to the reasons for the lack of enthusiasm for sports; elements that affect interest; passion for sports. In the future, the research will be aimed at developing the author's programme for designing a lesson based on the information received.

\section{REFERENCES}

[1] Salikhova, N.R., Lynch, M.F., \& Salikhova, A.B. (2019). The associations between tolerance for ambiguity and internal and external motivation in the scholarly activities of doctoral students. Education and Self Development, 14(4), 39-51.

[2] Juhász, T., Kálmán, B., \& Tóth, A. (2020). The impact of competitive individual school sports on the individual's future participation in competitive organisational situations (based on empirical evidence). Management and Marketing, 15(4), 664-674.

[3] Galeev, A.R., \& Pashchenko, L.G. (2020). Emotional reactions to and motives of university students for gto tests performance. Teoriya i Praktika Fizicheskoy Kultury, 12, 38-40.

[4] Sahli, H., Selmi, O., Zghibi, M., Hill, L., Rosemann, T., Knechtle, B., \& Clemente, F.M. (2020). Effect of the verbal encouragement on psychophysiological and affective responses during small-sided games. International Journal of Environmental Research and Public Health, 17(23), article number 8884.

[5] Granizo, I.R. (2018). Analysis of the motivational climate in sport and its relationship with the use of videogames and gender in elementary students. Facultad De Educacion y Humanidades Del Campus De Melilla, 48(2), 97-111.

[6] Oliveira, V.M., Brasil, M.R., Mattes, V.V., Menegaldo, P.H.I., Da Silva Souza, N.B., \& Ribas, S. (2020). Influence of the environment on sports motivation: Comparison between systematized and non-systematized spaces for practice. Motricidade, 16(4), 400-410.

[7] Granero-Gallegos, A. (2020). New developments in physical education and sport. International Journal of Environmental Research and Public Health, 17(24), article number 9171. 
[8] Irkhina, I.V., Nikulin, I.N., Isaev, I.F., \& Krolevetskaya, E.N. (2021). Academic educational provisions to motivate students for physical education practices. Teoriya i Praktika Fizicheskoy Kultury, 3, 31-32.

[9] Granero-Gallegos, A., Gómez-López, M., González-Hernández, J., Baena-Extremera, A., \& Ortiz-Camacho, M.M. (2018). Spanish adaptation and psychometric properties of the sport motivation scale-II with high school physical education students. International Journal of Environmental Research and Public Health, 15(12), article number 2768.

[10] Froiland, J.M. (2018). Promoting gratitude and positive feelings about learning among young adults. Journal of Adult Development, 25(10), 251-258.

[11] Danesh, J., \& Shahnaazari, M. (2020). A structural relationship model for resilience, L2 learning motivation, and L2 proficiency at different proficiency levels. Learning and Motivation, 72, article number 101636.

[12] Gordeeva, T.O., Sychev, O.A., \& Sidneva, A.N. (2021). Assessment of school student achievement in traditional vs developmental education: Psychological and pedagogical analysis. Educational Studies, 1, 213-236.

[13] Soltani, A., \& Askarizadeh, G. (2021). How students' conceptions of learning science are related to their motivational beliefs and self-regulation. Learning and Motivation, 73, article number 101707.

[14] Almagro, B.J., Sáenz-López, P., Fierro-Suero, S., \& Conde, C. (2020). Perceived performance, intrinsic motivation and adherence in athletes. International Journal of Environmental Research and Public Health, 17(24), article number 9441.

[15] Chernyaeva, I.A., \& Petrov, I.F. (2018). Questionnaire as an actual method of sociological research. Alley of Science, 9(25), 170-173.

[16] Saati, T.L. (1989). Making decisions. Hierarchy analysis method. Moscow: Radio and communication.

[17] Shin, M., \& Bolkan, S. (2021). Intellectually stimulating students' intrinsic motivation: The mediating influence of student engagement, self-efficacy, and student academic support. Communication Education, 70(2), 146-164.

[18] Gil-Arias, A., Diloy-Peña, S., Sevil-Serrano, J., García-González, L., \& Abós, Á. (2021). A hybrid TGfU/SE volleyball teaching unit for enhancing motivation in physical education: A mixed-method approach. International Journal of Environmental Research and Public Health, 18(1), article number 110.

[19] Román, N., Rigó, A., Kato, Y., Horváth, Z., \& Urbán, R. (2021). Cross-cultural comparison of the motivations for healthy eating: Investigating the validity and invariance of the motivation for healthy eating scale. Psychology and Health, 36(3), 367-383.

[20] Janke, S. (2020). Prospective effects of motivation for enrollment on well-being and motivation at university. Studies in Higher Education, 45(12), 2413-2425.

[21] Aoyagi, K., Ishii, K., Shibata, A., Arai, H., Fukamachi, H., \& Oka, K. (2020). A qualitative investigation of the factors perceived to influence student motivation for school-based extracurricular sports participation in Japan. International Journal of Adolescence and Youth, 25(1), 624-637.

[22] Kiremitci, O., Boz, B., \& Engür, M. (2020). Relationship between academic motivation and student alienation: A study of undergraduate students of sports sciences. Croatian Journal of Education, 22(4), 1283-1315.

[23] Gavrishova, E.V., Grachev, A.S., \& Tretyakov, A.A. (2020). Use of information and communication technologies in additional physical training and sport activities of students based on motivation type. Teoriya i Praktika Fizicheskoy Kultury, 1, 44-47.

[24] Kerstajn, R., Lupo, C., Capranica, L., \& Topic, M.D. (2018). Motivation towards sports and academics careers in elite winter sport Slovenian and Italian athletes: The role of internal and external factors. Ido Movement for Culture, 18(2), 29-37.

[25] Shi, Y., Tong, M., \& Long, T. (2021). Investigating relationships among blended synchronous learning environments, students' motivation, and cognitive engagement: A mixed methods study. Computers and Education, 168, article number 104193.

[26] Samendinger, S., \& Hill, C.R. (2021). Exercise schema and motivational regulation of college students: A personcentered analysis. Psychology of Sport and Exercise, 54, article number 101921.

[27] Khalilzadeh, S., \& Khodi, A. (2021). Teachers' personality traits and students' motivation: A structural equation modeling analysis. Current Psychology, 40(4), 1635-1650. 


\author{
Юе Чжан ${ }^{1}$ Шань Цін ${ }^{1}$, Ірина Сергіївна Кравець \\ ${ }^{1}$ Університет Янчжоу \\ 225009, 88 Південна дорога Даксу, м. Янчжоу, Китайська Народна Республіка \\ ${ }^{2}$ Київський національний університет імені Тараса Шевченка \\ 01033, вул. Володимирська, 64, м. Київ, Україна
}

\title{
Особливості внутрішньої мотивації сучасних студентів до занять фізичними вправами
}

\begin{abstract}
Анотація. Сучасний спосіб життя сприяє зменшенню рухової активності та зниженню витрат м'язової енергії у поєднанні 3 нервово-психологічними перевантаженнями. Виходячи 3 цього, основна мета роботи полягає у виявленні особливостей внутрішньої мотивації сучасних студентів до занять фізичними вправами. Для досягнення поставленої мети були використані методи анкетування серед 75-ти студентів Технологічного інституту Яньчена, а також метод аналізу отриманої інформації. Унаслідок дослідження були встановлені причини відсутності зацікавленості до занять спортом з особистої ініціативи, серед яких можна виокремити відсутність наочного прикладу батьків, проблеми зі здоров'ям, програму навчального курсу тощо. Визначено, що половина опитаних студентів має пасивне ставлення до фізичних занять та спорту загалом, оскільки уроки фізичної культури відвідують час від часу. Також у роботі були виявлені показники мотивації (залежно від курсу навчання). Виявлено, що серед першого курсу найбільше значення має оточення (52 \% респондентів), третього здоровий спосіб життя (54 \% опитуваних). За допомогою методу аналізу ієрархій було обрано сім найбільш значимих мотиваційних критеріїв, які дали змогу визначити, що комунікаційні мотиви є найважливішими. Це пов'язано з тим, що адаптація в колективі має першочергове значення для студентів молодших курсів. Отримані результати експерименту свідчать про наявність нерозривного зв’язку між внутрішніми та зовнішніми чинниками мотивації в занятті фізичними вправами. Лише комплексний підхід сприяє внутрішній зацікавленості молодого покоління. Результати статті мають першочергове значення для викладачів вищого навчального закладу під час складання навчальних програм, що посприяє зацікавленості студентів до уроку
\end{abstract}

Ключові слова: фізична активність, комунікація, метод аналізу ієрархій, анкетування, вид спорту, здоровий спосіб життя 